\title{
Expansin genes expression in growing ovaries and grains of sunflower are tissue-specific and associate with final grain weight
}

Francisca M. Castillo ${ }^{1,2}$, Javier Canales ${ }^{3,4}$, Alejandro Claude ${ }^{3}$ and Daniel F. Calderini ${ }^{2 *}$

\begin{abstract}
Background: Grain weight (GW) is a key component of sunflower yield and quality, but may be limited by maternal tissues. Cell growth is influenced by expansin proteins that loosen the plant cell wall. This study aimed to identify spatio-temporal expression of EXPN genes in sunflower reproductive organ tissues (ovary, pericarp, and embryo) and evaluate correlations between reproductive organ growth and expansin genes expression. Evaluations involved eight different developmental stages, two genotypes, two source-sink treatments and two experiments. The genotypes evaluated are contrasting in GW (Alybro and confection variety RHA280) under two source-sink treatments (control and shaded) to study the interactions between grain growth and expansin genes expression.

Results: Ovaries and grains were sampled at pre- and post-anthesis, respectively. Final GW differed between genotypes and shading treatments. Shading treatment decreased final GW by 16.4 and 19.5\% in RHA280 and Alybro, respectively. Relative expression of eight expansin genes were evaluated in grain tissues. EXPN4 was the most abundant expansin in the ovary tissue, while EXPN10 and EXPN7 act predominantly in ovary and pericarp tissues, and EXPN1 and EXPN15 in the embryo tissues.

Conclusions: Specific expansin genes were expressed in ovary, pericarp and embryo in a tissue-specific manner. Differential expression among grain tissues was consistent between genotypes, source-sink treatments and experiments. The correlation analysis suggests that EXPN genes could be specifically involved in grain tissue extension, and their expression could be linked to grain size in sunflower.
\end{abstract}

Keywords: Expansin, Grain tissues, Grain weight, Source-sink ratio, Gene expression, Sunflower

\section{Background}

In the last 50 years, oil crops such as soybean, sunflower, and oilseed rape have become increasingly important in international food trade, due to increased human consumption and demand of oil for biofuel production. Sunflower has had the third highest relative growth among crop commodities; it contributes to calorific intake [1] and provides about $8 \%$ of global oil production [2]. To meet the increasing food demand, sunflower grain and oil yield must both be improved. Grain weight (GW) is a

\footnotetext{
* Correspondence: danielcalderini@uach.cl

${ }^{2}$ Plant Production and Plant Protection Institute, Faculty of Agricultural

Sciences, Universidad Austral de Chile, Valdivia, Chile

Full list of author information is available at the end of the article
}

key trait affecting sunflower yield and quality, yet a systematic understanding of physiological and molecular drivers of GW is still lacking for sunflower and other oil crops. Most studies of GW and grain size determination have focused on the grain filling period. Physiological studies have assessed associations between GW and key post-flowering factors such as maximum water content in wheat [3-5], maize [6, 7], and sunflower [8]. However, little is known about the genetic determination of grain water dynamics. Genetic studies have also focused on the post-flowering period, where GW has been identified as a quantitative trait controlled by multiple genes [913]. Scant information is available about the genetic control of GW during the pre-flowering phase, though it

(c) The Author(s). 2018 Open Access This article is distributed under the terms of the Creative Commons Attribution 4.0 International License (http://creativecommons.org/licenses/by/4.0/), which permits unrestricted use, distribution, and reproduction in any medium, provided you give appropriate credit to the original author(s) and the source, provide a link to the Creative Commons license, and indicate if changes were made. The Creative Commons Public Domain Dedication waiver (http://creativecommons.org/publicdomain/zero/1.0/) applies to the data made available in this article, unless otherwise stated. 
has recently been demonstrated that GW determination in sunflower is a continuous process from early pre-anthesis (R3 stage: reproductive stage when ovaries are growing) to physiological maturity (PM: when GW reaches its maximum value with a water content about 38\%) [14], challenging the general assumption that flowering is a pivotal phenological stage for GW determination. In order to fully understand GW determination, an integrated physiological and molecular approach, linking the pre and post-anthesis periods, is necessary in sunflower.

The sunflower grain is an achene comprised of two main components: the pericarp (coat or hull), resulting from the fusion of the ovary tissues and part of the receptacle (maternal origin), and the embryo, formed by two cotyledons and a small stem and radicle, derived from the egg fertilization. The mature sunflower grain lacks endosperm (it is consumed during embryo growth), thus grain reserves (lipids, carbohydrates, and proteins) accumulate within embryo cells, mainly in the cotyledons [15].

The relationship between the pre- and post-anthesis periods has been attributed to the flower ovary, which becomes the pericarp after pollination in sunflower and other crops [4, 14, 16]. Grain maternal tissues (ovary/ pericarp) undergo rapid cell division and expansion, which in turn may impose a physical limit to the endosperm or embryo of the grain, suggesting that maternal tissues control potential grain size [17-25]. However, these suggestions are still speculative and the physiological and molecular processes through which the continuous ovary-pericarp growth controls grain size are only starting to be known [3, 25-28].

Lindstrom et al., (2006) [29] and Castillo et al., (2017) [14], showed that GW of sunflower is much more sensitive than grain number to lower source-sink ratios during the period before flowering ( $\mathrm{R} 2$ to R5), being R2 the stage immediately after floral initiation, when cell division in the ovary wall ceased, and R5 when anthesis of external flowers starts. In addition, Lindstrom et al., (2007) [30] showed that shading at pre-anthesis reduced GW and the number of pericarp middle layer strata, supporting the hypothesis that GW determination is a continuum process. Maternal tissues evolve from the ovary to the pericarp, a process driven by complex regulation involving cell division and expansion, utilization of assimilates, and the interaction of many genes and signals [31, 32]. Cell size depends on the cell capacity for enlargement and extension; while the plant cell wall must be strong enough to contain the turgor of plant cells, its extensibility also determines plant cell expansion [33, 34]. Several cell wall enzymes and proteins have been implicated in the loosening process that occurs during cell growth, including expansin (EXPN) proteins $[35,36]$ and xyloglucan endotransglucosylase/hydrolase [37]. EXPN have been known as "factors that loosen the cell wall", playing a major role in plant cell growth by enabling plant cell expansion [38], among other processes ([39] and citations therein). However, the role of EXPN in grain growth is currently poorly understood.

In multigene families such as EXPN, different members may play unique developmental or tissue-specific roles, though there is currently little information about the role of EXPN in specific grain tissues. Lizana et al. (2010) [3] conducted an experiment on wheat and found clear relationships between grain size dynamics, water content, and EXPN expression in pericarp tissues. Meanwhile, when overexpressed in Arabidopsis, the sweet potato EXPN1 gene (IbEXP1) positively affected grain size and brassinosteroid signaling pathways [40]. In barley, the gene expression of nine genes involved in cell wall biosynthesis shows a broad maximum between 3 and 10 days after flowering [41]. Much less information is available about the role of EXPN in sunflower grain growth, thus this study aimed to address the following questions: i) are ovary and grain growth associated with EXPN expression at both pre- and post- flower fertilization? ii) is pericarp and embryo enlargement driven by different EXPN? iii) is the timing of EXPN expression similar for the pericarp and embryo? and iv) is the effect of EXPN on GW mediated by the abundance, rate, or duration of EXPN expression? To answer these questions, we identified the EXPN involved in ovary and grain growth by measuring mRNA gene transcripts and their time-course expression in field experiments. A high-quality reference database for the sunflower genome (3.6 gigabases) was also utilized, together with extensive transcriptomic data from vegetative and floral organs [42].

\section{Results \\ Environmental conditions, crop phenology, and grain weight}

Climate conditions were similar between experiments. Mean temperature during the Emergence-R1 period was only $1.1^{\circ} \mathrm{C}$ higher in experiment 1 , while the $\mathrm{R} 1$ to $\mathrm{PM}$ average temperature was higher in experiment 2 , primarily during R2-R5, when the mean temperature was $3^{\circ} \mathrm{C}$ higher in experiment 2 than in experiment 1 (see Table A1 in [14]). Crop development was similar in both growing seasons in Alybro reaching anthesis (R5) at 74 days after emergence. In experiment 2, phenology between Alybro and RHA280 was similar, the R5 and PM was later in Alybro than in RHA280 but only by 2 days at each stage (see Fig. 1 in [14]). 


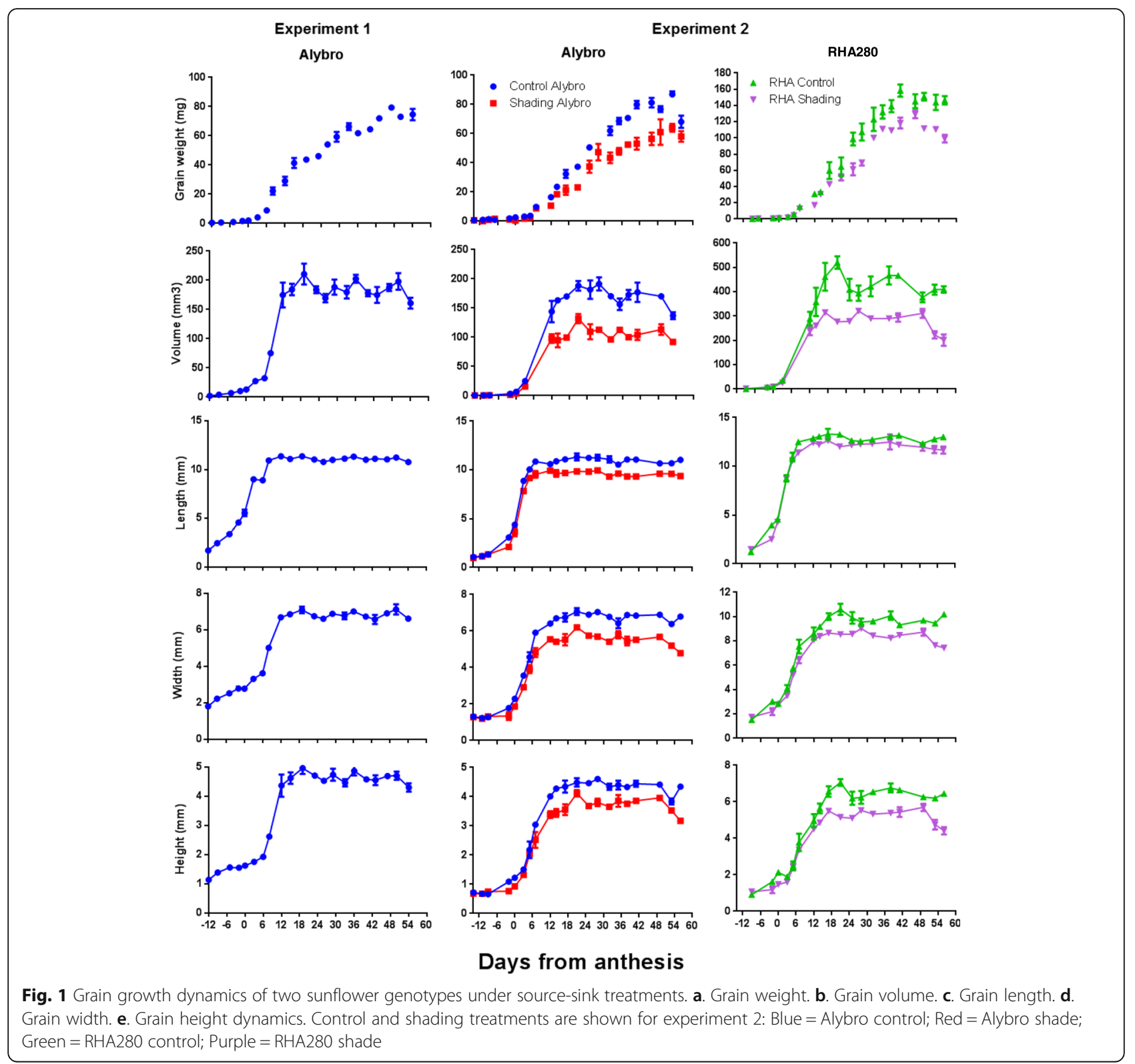

Final GW of Alybro was $76.5 \mathrm{mg}$ in experiment 1 and 79.2 and $58.2 \mathrm{mg}$ in experiment 2 under control and shaded treatments, respectively. As expected, the confection genotype RHA280 reached higher $(p<0.05) \mathrm{GW}$ than Alybro in both the control treatment $(148.8 \mathrm{mg}$, $47 \%$ higher) and under shading ( $107 \mathrm{mg}, 46 \%$ higher) of experiment 2 (Table 1). Ovary weight of Alybro at R3 and R5 was slightly higher in experiment 1 than in experiment 2 (Table 1). In the last experiment, RHA280 ovary weight was significantly greater $(\mathrm{p}<$ 0.05 ) than the ovary weight of Alybro at both R3 and R5 phenological stages [14]. The reduction of the source-sink ratio by the shading treatment had a strong impact on ovary weight at anthesis $(p<0.001)$, decreasing it by 45 and 33\% in Alybro and RHA280, respectively (Table 1$)$. The shading treatment also negatively affected grain dimensions $(p<0.001)$; grain length was reduced by 13 and 5.4\% in Alybro and RHA280, respectively, while grain width decreased by $19 \%$ in Alybro and $14 \%$ in RHA280, and grain height decreased by 16 and $20 \%$ in Alybro and RHA280, respectively (Table 1 ).

Figure 1 illustrates the time-course of $\mathrm{GW}$, grain volume and dimensions across experiments 1 and 2. Alybro showed similar GW, volume, and dimension dynamics in both experiments, while RH280, evaluated only in experiment 2, reached higher rates than Alybro across all measured traits (Fig. 1). The lower source-sink ratio before anthesis (under the shading treatment) reduced GW and volume in both Alybro and RHA280 compared 
Table 1 Physiological traits of grains in experiments 1 and 2 of sunflower genotypes

\begin{tabular}{|c|c|c|c|c|c|c|c|c|c|c|c|c|}
\hline \multirow[t]{2}{*}{ Exp } & \multirow[t]{2}{*}{ Genotype } & \multirow{2}{*}{$\begin{array}{l}\text { Source-Sink } \\
\text { treament }\end{array}$} & \multicolumn{6}{|c|}{ Dry weight (mg) } & \multicolumn{4}{|c|}{ Dimensions (mm) } \\
\hline & & & Ovary at R3 & Ovary at R5 & Grain & Pericarp & Embryo & Grain/pericarp & Length & Width & Height & $\begin{array}{l}\text { Embryo } \\
\text { length }\end{array}$ \\
\hline 1 & Alybro & Control & 0.33 & 1.94 & 76.5 & 20.3 & 58.0 & 3.9 & 11.1 & 6.8 & 4.6 & 8.7 \\
\hline \multirow[t]{8}{*}{2} & Alybro & Control & 0.24 & 1.60 & 79.2 & 20.2 & 60.9 & 3.9 & 11.0 & 6.8 & 4.4 & 8.4 \\
\hline & & Shading & 0.23 & 0.88 & 58.2 & 14.1 & 46.4 & 4.1 & 9.6 & 5.5 & 3.7 & 7.5 \\
\hline & RHA280 & Control & 0.41 & 2.60 & 148.8 & 76.1 & 73.2 & 2.0 & 13.0 & 9.8 & 6.5 & 9.9 \\
\hline & & Shading & 0.37 & 1.75 & 107.0 & 58.1 & 61.5 & 1.8 & 12.3 & 8.4 & 5.2 & 9.0 \\
\hline & s.e.m & & 0.03 & 0.23 & 10.4 & 6.6 & 6.2 & 0.4 & 0.4 & 0.5 & 0.3 & 0.3 \\
\hline & Genotype & & a & a & a & a & a & a & a & a & a & a \\
\hline & Source-sink ratio & & ns & a & a & a & a & * & a & a & a & a \\
\hline & Genotype x Source-sink & & ns & ns & ns & a & a & ns & a & ns & a & a \\
\hline
\end{tabular}

Values are means of three replicates. $n s$ means not significant effects. ${ }^{*}$ Significant effects at $P<0.05 .{ }^{*}$ Significant effects at $P<0.01$

${ }^{a}$ Significant effects at $P<0.001$ (modified from Castillo et al., 2017)

to the control treatment, mainly by decreasing the grain filling rate (Fig. 1).

In experiment 2, the differences between the control and shading treatments were observed early during grain growth (+ 6 days from anthesis, DFA) in both pericarp weight and water content (Fig. 2). Pericarp weight dynamics were similar between the two growing seasons for Alybro (Fig. 2 a), though the maximum pericarp water content was higher in experiment 1 than in experiment 2 (Fig. 2b).

Classifying sunflower EXPN by phylogenetic relationships and comparative analysis of the gene structure

Genome databases were used to evaluate the role of EXPN in specific tissues of sunflower grains. According to the phylogenetic tree, the sunflower EXPN selected in this study are part of the $\alpha$-EXPN subfamily, and the gene models showed that each EXPN had a conserved intron/exon structure and protein domain, supporting their close evolutionary relationship (Fig. 3). In the $\alpha$-EXPN subfamily, all sunflower EXPN genes had 3 exons and 2 introns, and orthologs (soybean, rice, and maize) had 2 exons and 1 intron (Fig. 3). Sunflower EXPN proteins share $65.9-95.9 \%$ of their identity with each other, and over $60 \%$ of their identity is shared with EXPN7 orthologs (Additional file 1: Figure S1). As expected, the identity shared among EXPN from different groups was low: maize $\beta$-EXPN (EXPNB1) shared 26.8-29.1\% identity with $\alpha$-EXPN, while EXLX1 shared 14.9-18.9\% identity with $\alpha$-EXPN (Additional file 1: Figure S1).

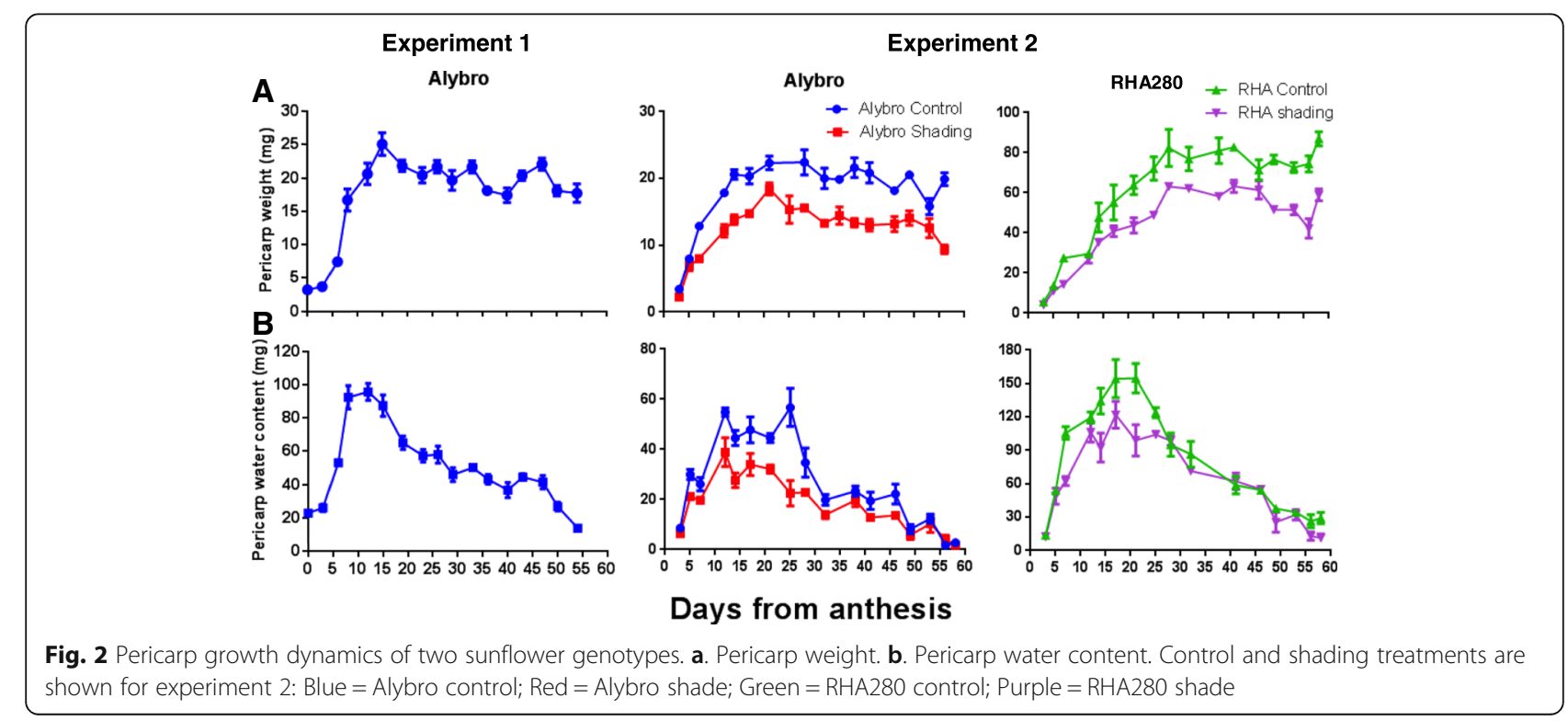




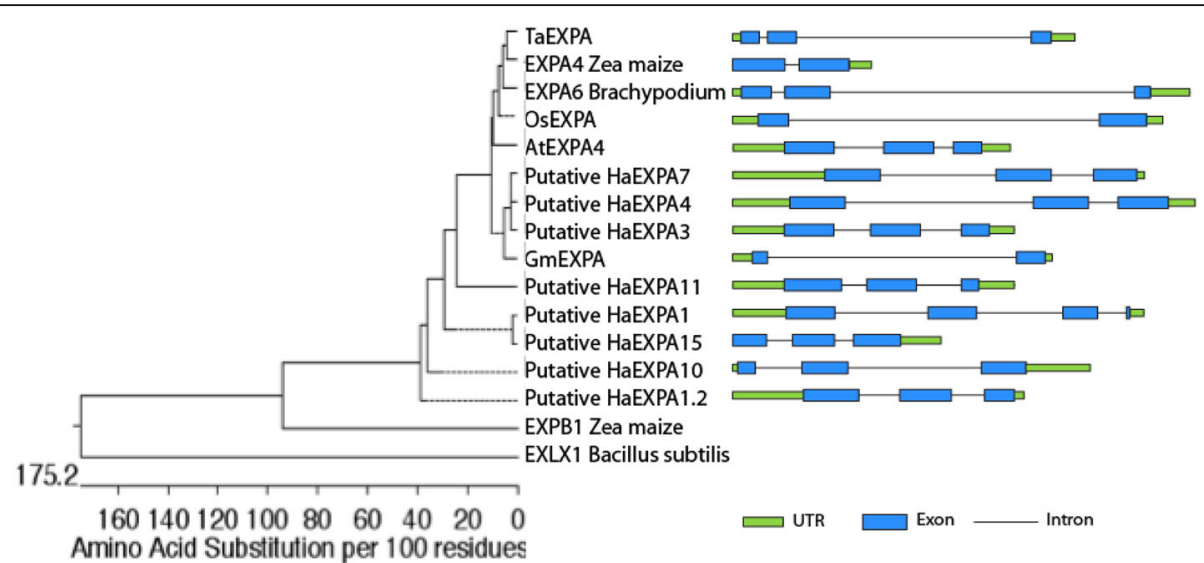

Amino Acid Substitution per 100 residues

Fig. 3 Phylogenetic tree of eight putative EXPN of sunflower, orthologs of EXPN7, EXPB1, EXLX1. Phylogenetic relationship of Arabidopsis, soybean, rice, maize, wheat, brachypodium, and sunflower EXPN genes. The phylogenetic tree was constructed based on a conserved domain of predicted protein sequences using MegAlign software. The gene model is indicated to the right of each EXPN

EXPN expression is arranged in a temporal and tissuespecific manner during ovary and grain growth

The "Clustvis bioinformatics tool" [42] was used to visualize the gene expression patterns of the eight selected EXPN genes and to perform a comparative gene expression analysis along the grain growth across genotypes, experiments and treatments. EXPN gene clustering between both experiments indicated two main groups, according to their expression patterns (Fig. 4a). In one group, EXPN were expressed mainly in maternal tissues (EXPN7, EXPN11, EXPN10, EXPN4), while in the other they were mainly expressed in embryo tissues (EXPN1, EXPN1.2, EXPN3, EXPN15). The clustering and heatmap showed that two EXPN from each group have similar expression patterns across experiments and genotypes, i.e. EXPN 7 and 11 in pericarp, and EXPN 1 and 15 in embryo tissues (Fig. 4). Differential expression among grain tissues was consistent between genotypes (Fig. 4b). PCA was performed with relative gene expression of EXPN7, EXPN11, and EXPN4 (mainly expressed in maternal tissues) and EXPN1 and EXPN 15 (predominantly expressed in embryo tissues), accounting for $64.2 \%$ of the total variation (Fig. 4c). When PCA of the relative EXPN gene expression was performed using the entire dataset, a lower percentage of the total variation (45.2\%) was found (data not shown). Expression data was grouped into two main groups according to tissue expression (Fig. 4c). EXPN4 showed more abundant relative expression (mainly in the ovaries; Fig. 4f) compared to all other EXPN evaluated in this study, followed by EXPN1 and EXPN7 (Additional file 2: Figures S2L and $4 \mathrm{D}$, respectively).

EXPN11 had the most consistent expression pattern across genotypes, treatments, and experiments, peaking at anthesis in both experiments, 1 and 2 (Fig. 4b). The relative abundance of EXPN11 was higher in RHA280 than in Alybro in experiment 2, but the shading had little effect on relative abundance (Additional file 2: Figure S2J). EXPN7 was expressed in maternal tissues of both genotypes, though in experiment 1 , it peaked at +6 DFA in the pericarp of Alybro, whereas under the control treatment of experiment 2, it peaked at anthesis in the pericarp of both Alybro and RHA280, before decreasing. In both experiments, EXPN7 was expressed earlier in ovary tissues, from - 12 DFA (Fig. 4b, d). In experiment 1, EXPN4 was expressed in the ovary of Alybro from - 12 DFA, peaking at +6 DFA in the pericarp. In experiment 2, EXPN4 was more consistent in its expression patterns between the two genotypes; it was more abundant in ovary tissues (peaking at - 12 DFA) under control treatments, and under shading treatments maintained high expression levels between - 12 and-6 DFA in both genotypes. EXPN4 was also expressed in embryo tissues in both genotypes and experiments, but at lower relative expression levels (Fig. 4b, f). In Alybro (both experiments) EXPN10 expression in the pericarp peaked between +15 and +23 DFA, whereas the peak in RHA280 was earlier, at +6 and + 12 DFA (Fig. 4b,e).

EXPN1.2 was expressed in both pericarp and embryo tissues. Expression was higher in the pericarp, which peaked later than other EXPN in the pericarp (+23 DFA in Alybro for both experiments, and between +15 and +23 DFA in RHA280). On the other hand, the peak expression of EXPN1.2 in the embryo was at + 6 DFA in control treatments of both genotypes (Fig. 4b). The shading treatment decreased the expression levels of EXPN1.2, mainly in the pericarp, and shifted the RHA280 peak from +23 to +33 DFA (Fig. 4b; Additional file 2: Figure S2K). Meanwhile EXPN1 was expressed mainly in embryo tissues and later than other EXPNs (+ 23 and + 33 DFA) in both genotypes 

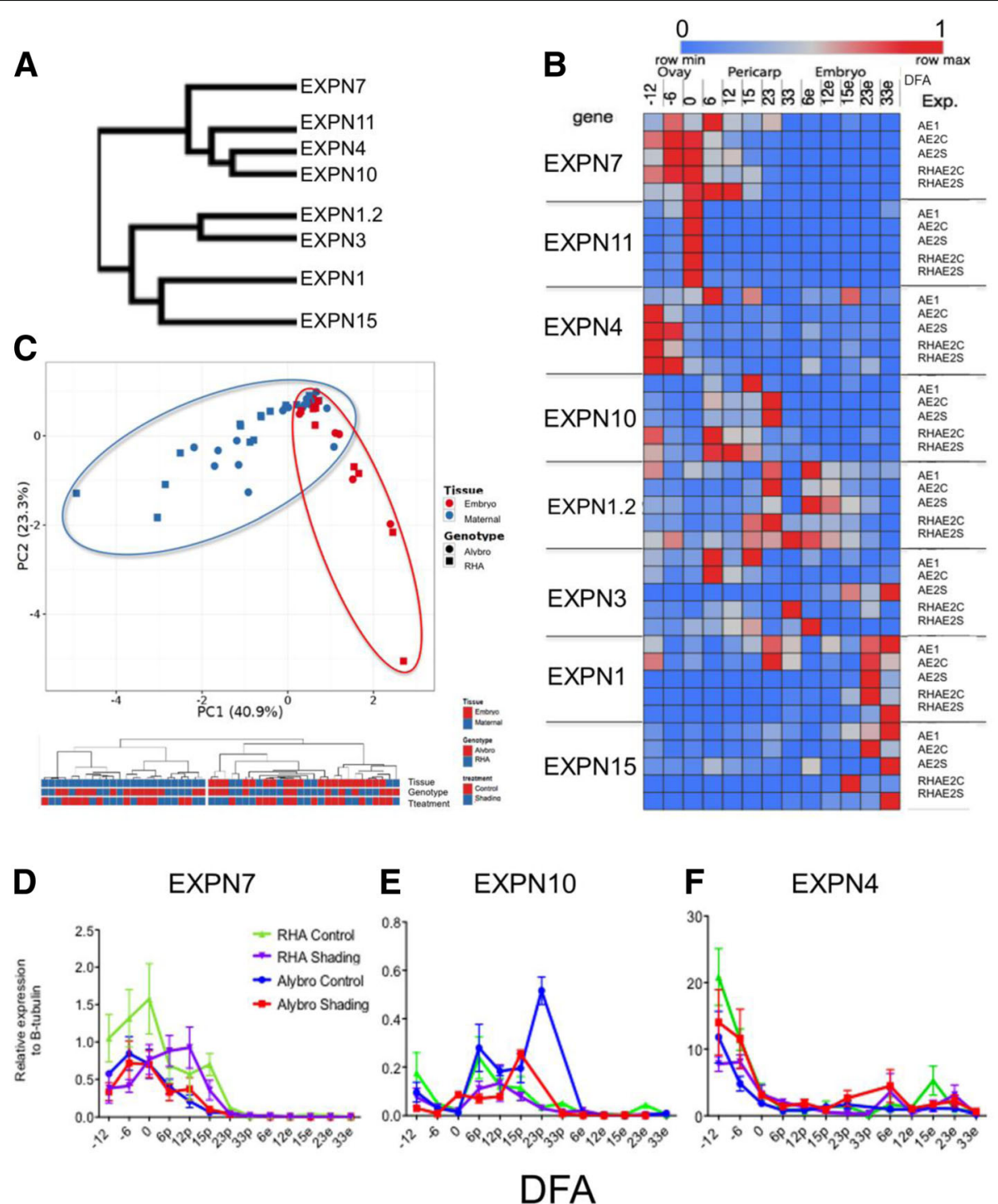

Fig. 4 Clustering, heatmap and principal component analysis (PCA) of EXPN expression in sunflower ovaries and grains (pericarp and embryo). a. Clustering based on EXPN expression patterns. b. Heatmap showing EXPN expression patterns. Expansin expression levels were compared by Z score using the Clustvis bioinformatics tool. Columns names indicate the days from anthesis (DFA) in which the expression was measured (e $=$ embryo). Rows name on the left show the EXPN genes evaluated and row names on the right indicate the experiment where EXPN expression was evaluated, including genotype, treatment, and growing season ( $A=$ Alybro; $R H=R H A 280 ; E 1=$ experiment $1 ; C=$ control; $S=$ shade). $c$. $P C A$ with all EXPN expression data grouped into two main groups according to tissue expression (blue and red circle in PCA). $\mathbf{d}$. Relative expression of EXPN7 to $\beta$-tubulin. e. Relative expression of EXPN10. f. Relative expression of EXPN4

and experiments. Similarly, mRNA of EXPN15 was detected preferentially in the embryo at $+15,+23$ and +33 DFA in both genotypes and experiments (Fig. $4 \mathrm{~b}$ ).

\section{Correlation between physiological traits of grain and EXPN expression patterns in sunflower}

To explore if physiological grain traits correlate with EXPN expression patterns, we performed a correlation analysis using all data from two experiments. We used the Gini correlation coefficient to estimate the relationship between phenotypic traits and gene expression levels. The Gini correlation coefficient can compute the correlation of two variables considering both rank and value information. For this reason, this methodology is more robust on non-normally distributed data and is more stable for data containing outliers than the widely used Pearson correlation coefficient.

Qualitatively, EXPN7 follows a similar - but inverse time course than the grain growth pattern (Additional file 2: Figure S2G). Specifics EXPNs associated with the extension of the ovary, pericarp and embryo. EXPN7, EXPN10, and EXPN11 were found to be specific to 
maternal tissues (Fig. 4b, Additional file 2: Figure S2), while EXPN1 and EXPN15 were more abundant in embryo tissues (Fig. 4b, Additional file 2: Figure S2).

Physiological traits that showed significant correlations with EXPN expression patterns over time (at eight moments of sunflower development, Figs. 4, 5) are listed in Tables 2 and 3. Negative correlations mean that the grain growth dynamics follow a similar but inverse time course to the EXPN expression patterns, i.e. EXPN transcripts were accumulated when grain growth rates started and expression decreased according to the growth of the ovary/grain. The highest negative correlation was found between physiological traits and EXPN10 patterns in the maternal tissues, where the Gini correlation coefficient ranged from -0.70 to -0.86 (Table 2). GW was negatively correlated with EXPN7 (0.72 ), and most of the assessed physiological traits negatively correlated with the relative expression of EXPN7 in both the ovary and pericarp, ranging from -0.50 to 0.72 (Table 2).

In embryo tissues the best correlations were shown by EXPN4 and EXPN1, i.e. -0.76 between grain weight and EXPN4 and 0.75 between embryo weight and EXPN1 (Table 3). EXPN1 had significant positive correlations with grain volume, GW, embryo weight, grain width and grain height, while EXPN1.2 was associated with grain volume, grain length, and grain height (Table 3 ). EXPN15 correlated positively with all the physiological

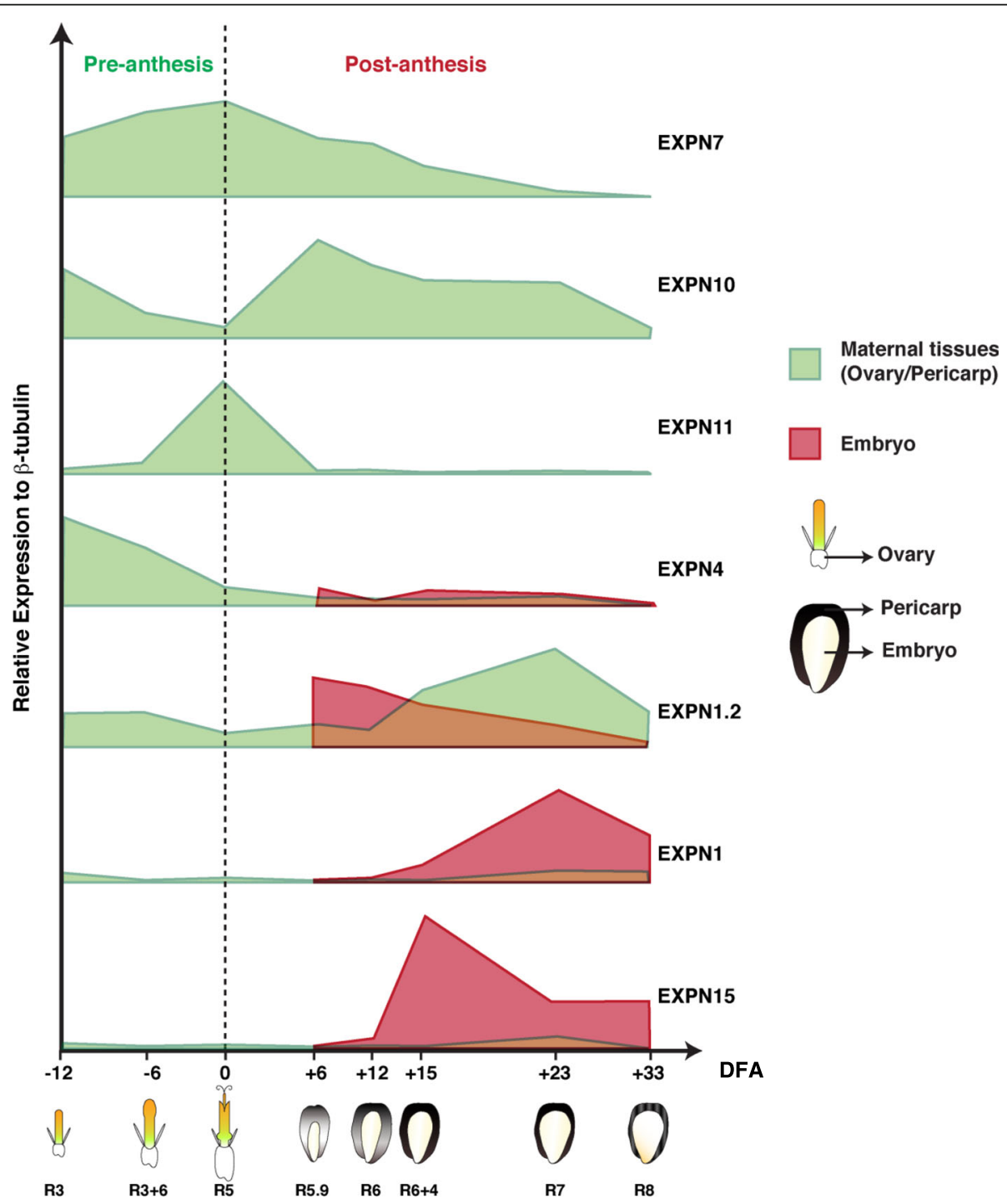

Fig. 5 Schematic model representing expression patterns of seven EXPN genes during sunflower ovary and grain growth. Relative expression of EXPN genes is based on qRT-PCR analysis from samples harvested at various days from anthesis. The development stage according to Schneiter and Miller (1981) scale is indicated below each ovary and grain. The dashed line divides pre- and post-anthesis periods (DFA = Days from anthesis) 
Table 2 Correlation between physiological trait dynamics and EXPN expression patterns in maternal tissues. Gini correlation coefficient and corresponding levels of significance between physiological trait dynamics and EXPN expression patterns in maternal tissues (ovary and pericarp)

\begin{tabular}{|c|c|c|c|}
\hline $\begin{array}{l}\text { Physiological traits } \\
\text { dynamics }\end{array}$ & $\begin{array}{l}\text { EXPNs expression } \\
\text { patterns in } \\
\text { maternal tissues }\end{array}$ & $\begin{array}{l}\text { Correlation } \\
\text { coefficient }\end{array}$ & $P$-value \\
\hline Grain volume & EXPN10 & -0.84 & 0.000 \\
\hline Grain volume & EXPN7 & -0.52 & 0.002 \\
\hline Grain weight & EXPN7 & -0.72 & 0.000 \\
\hline Grain weight & EXPN10 & -0.83 & 0.000 \\
\hline Pericarp weight & EXPN10 & -0.71 & 0.000 \\
\hline Pericarp weight & EXPN7 & -0.58 & 0.000 \\
\hline Pericarp weight & EXPN4 & 0.42 & 0.023 \\
\hline Embryo weight & EXPN7 & -0.68 & 0.000 \\
\hline Embryo weight & EXPN10 & -0.72 & 0.000 \\
\hline Water content & EXPN10 & -0.85 & 0.000 \\
\hline Length & EXPN10 & -0.86 & 0.000 \\
\hline Length & EXPN7 & -0.50 & 0.002 \\
\hline Width & EXPN10 & -0.81 & 0.000 \\
\hline Width & EXPN7 & -0.53 & 0.001 \\
\hline Height & EXPN7 & -0.59 & 0.000 \\
\hline Height & EXPN10 & -0.80 & 0.000 \\
\hline Embryo length & EXPN10 & -0.70 & 0.000 \\
\hline Embryo length & EXPN7 & -0.54 & 0.000 \\
\hline
\end{tabular}

grain traits evaluated in this study (correlation coefficient of 0.63-0.77).

The expression patterns of individual EXPN were consistent between both seasons for most of the EXPN genes evaluated in this study, except for EXPN3 (Fig. 4b). A schematic model summarizing the most consistent data recorded in both experiments is shown in Fig. 5 .

\section{Discussion}

This study aimed to: i) identify EXPN genes expressed in sunflower reproductive organs (e.g. floret ovaries and grains; ii) assess tissue-specific EXPN expression in those organs; and iii) evaluate correlations between reproductive organs and EXPN expression. We identified eight putative EXPN acting in reproductive tissues (ovary, pericarp, and embryo) during the pre- and post-anthesis periods. Evaluations involved eight different developmental stages, two genotypes, and two source-sink treatments in two experiments. We found that all the EXPN selected using in silico analysis and the transcriptomic data, share a similar protein-conserved domain and a relatively simple intron/exon structure belonging to the $\alpha$-EXPNs subfamily (Fig. 1).
Table 3 Correlation between physiological trait dynamics and EXPN expression patterns in embryo tissues

\begin{tabular}{llll}
\hline $\begin{array}{l}\text { Physiological traits } \\
\text { dynamics }\end{array}$ & $\begin{array}{l}\text { EXPNs expression } \\
\text { patterns in } \\
\text { embryo tissue }\end{array}$ & $\begin{array}{l}\text { Correlation } \\
\text { index }\end{array}$ & $P$-value \\
\hline Grain volume & EXPN15 & 0.74 & 0.000 \\
Grain volume & EXPN1 & 0.56 & 0.002 \\
Grain volume & EXPN1.2 & -0.58 & 0.004 \\
Grain weight & EXPN4 & -0.76 & 0.000 \\
Grain weight & EXPN1 & 0.73 & 0.000 \\
Grain weight & EXPN15 & 0.77 & 0.000 \\
Pericarp weight & EXPN15 & 0.74 & 0.000 \\
Embryo weight & EXPN4 & -0.71 & 0.000 \\
Embryo weight & EXPN1 & 0.75 & 0.000 \\
Embryo weight & EXPN15 & 0.63 & 0.002 \\
Length & EXPN1.2 & -0.66 & 0.000 \\
Length & EXPN15 & 0.75 & 0.000 \\
Width & EXPN15 & 0.71 & 0.000 \\
Width & EXPN1.2 & -0.61 & 0.001 \\
Width & EXPN1 & 0.53 & 0.010 \\
Height & EXPN15 & 0.75 & 0.000 \\
Height & EXPN1 & 0.67 & 0.001 \\
Height & EXPN4 & -0.48 & 0.020 \\
Embryo length & EXPN15 & 0.74 & 0.001 \\
\hline Gini correlation coefficients and corresponding levels of significance between \\
physiological trait dynamics and EXPN expression patterns in embryo tissue
\end{tabular}

Expression pattern analysis using qRT-PCR supports the hypothesis that EXPN genes act in a tissue-specific and temporal manner in sunflower grains. Taking into account that other sunflower organs and tissues were not evaluated in this study, we only highlight its expression in reproductive tissues from the pre-flowering to post-flowering stages, considering that they may be acting in other organs. Similarities in expression patterns could indicate functional redundancy between EXPN of sunflower reproductive tissues, as was previously reported in grasses and other plant groups [43, 44]. Organ specific expression of Os-EXP1, Os-EXP2, and Os-EXP4 was found in rice [45]. A study of maize reproductive organs found at least $21 \mathrm{ZmEXPNs}$ genes, 16 of which were predominantly expressed in the tassel, while five ZmEXPNs were mainly expressed in the endosperm, suggesting their involvement in endosperm development and growth [46].

A central question of the present study was if differences in GW between genotypes and shading treatments were explained by the abundance or duration of EXPNs expression. The difference between Alybro and RHA280 genotypes (with different GW) was ascribed to relative abundance. In agreement with this response, most of the 
EXPN genes of both genotypes showed lower abundance under the lower source treatment (Fig. 4, Additional file 2: Figure S2). In addition, the negative effect of the source reduction on GW could be mediated by a later timing of the peak of EXPN expression. These finding agree with the decrease of the ovary growth rate by the shading treatment and a lower grain and pericarp growth rate reported previously of the evaluated genotypes [14]. A recent study showed that the transcript abundance of genes involved in cell expansion, such as EXPN genes, were significantly higher in the largeseeded chickpea cultivar [47], supporting our results of the different relative abundance between sunflower genotypes.

Cell expansion determines organ size and is powered by water uptake and expansion of the cell wall [48]. To understand the potential roles of grain water uptake and loss during grain filling the timing of key grain growth events is necessary. Grain water content serves as an engine to increase the turgor pressure in the vacuole powering cell expansion. Therefore, once grain desiccation commences, the driving force disappears and grain enlargement ends (at this time, all grain dimensions reach their maximum values) and this timing agrees with the expression pattern of EXPN7 and EXPN10. The time course of EXPNs expression was shown tissue-specific and seems to control the enlargement of the ovary, pericarp and embryo. The expression of EXPN4, EXPN7, EXPN10 and EXPN11 were found mainly in maternal tissues. Among them, EXPN4 was more abundant in the ovary/pericarp. On the other hand, EXPN1 (embryo), EXPN1.2 and EXPN 10 (pericarp) were expressed late during grain filling (between +15 and +33 DFA) in sunflower grains. These EXPNs could play a role in grain ripening, as it was previously reported in other crops, linking the EXPNs with grain or fruit maturation $[49,50]$.

Previous studies have shown expression analysis of genes related to cell wall and cell expansion. $\mathrm{H}+$-ATPases acidify cell walls, which activates EXPN, leading to cell wall synthesis and cell expansion [34]. Radchuk et al. (2011) [41] reported gene expression profiles of EXPN, together with the expression of related genes such as $\mathrm{H}$ +-ATPases, and enzymes of cell wall biosynthesis from the microarray data set in barley pericarp. In their study, five EXPN genes reached the highest expression 3-4 DFA and $\mathrm{H}+$-ATPase exhibited the highest gene expression 210 DFA. The maximum expression of nine genes involved in cell wall biosynthesis was 3-10 DFA. This pattern of gene expression aligns with pericarp growth, where cell expansion and cell wall synthesis occur 3-10 DFA in barley [41]. Our study of sunflower found that EXPN7, EXPN 4, EXPN10, and EXPN11 would play key roles early in grain development, until pericarp growth levels off soon after flowering, i.e. +8 DFA at R5.1. Maximum pericarp water content was attained by + 10 DFA (Fig. 3), concurring with other studies $[8,51]$ and reinforcing the link between EXPN expression and water dynamics of sunflower grains. In our study, EXPN expression patterns suggest an earlier specific role (from - 12 to + 6 DFA) for EXPN7 and EXPN10 in the ovary and pericarp, respectively, compared with other isoforms. This agrees with Lindström and Hernández (2015) [51], who demonstrated that final pericarp size is attained at +8 DFA when secondary wall deposition in the pericarp cells begins.

The correlation analysis supports the qualitative analysis (heatmap, expression dynamics, and grain growth dynamics) and suggests that EXPN genes could be specifically involved in grain tissue extension, and their expression could be linked to grain size in sunflower (Fig. 5). EXPN4 was abundant in ovary tissues, while EXPN10 and EXPN7 were specifically expressed in the ovary and pericarp tissues, and EXPN1 and EXPN15 in the embryo. These results would indicate that EXPN isoforms are linked to flower and grain growth in sunflower.

On the other hand, the grain growth process integrates and coordinates different pathways like genetics, epigenetics, metabolic, physiological, and environmental factors [52-57]. Several genes acting in maternal tissues have been identified in different plant species [19, $25,58-62]$. For example, introgression of the mutant TaGW2-A1 allele (a gene that negatively regulates cell number in maternal tissues) showed an association between final GW and carpel size in wheat [63], reinforcing the importance of maternal tissues on GW determination. Furthermore, recent studies found that pericarp cell length correlates with, and affects the, final grain size and weight in wheat and tomato [25, 62, 64]. Meanwhile, transgenic overexpression of GhRDL1 (a cell wall protein that interacts with GhEXPN1) in cotton and GhEXPN1 in Arabidopsis produced more and larger grains in both species [40,65]. Moreover, the overexpression of sweet potato EXPN gene IbEXP1 in Arabidopsis, under the control of the $35 \mathrm{~S}$ promoter, also resulted in larger grains than the control plants [40]. Previous studies have been shown, through overexpression and/or RNAi approaches, that EXPN proteins are a key for fruit ripening, growth of root hairs, tolerance to abiotic and biotic stresses, among others [39]. Our findings of specific EXPN (e.g. EXPN4, EXPN7, and EXPN10) expressed in maternal tissues of sunflower grains enable us to hypothesize that these EXPN are a key component of ovary/pericarp growth. The present findings and the previous knowledge about the involvement of EXPNs on grain growth of crops $[3,21,39,41,65]$, allow us to speculate that results of this study provide tools for improving sunflower GW by cloning and/or overexpressing them as it was shown in the model plant Arabidopsis where grain size was increased 
[40] and improved grain production in Tobacco [66]. Alternatively, the development of molecular markers based on information reported in the present study could also be useful for breeding programs.

\section{Conclusions}

The molecular and physiological bases of GW and grain size determination can be studied in an integrated manner by using a quantitative molecular approach combined with physiological and agronomical studies. Using qualitative and quantitative analysis of grain growth and expression dynamics, combined with heatmap and correlation analysis, we identified eight putative EXPN genes that could be involved in grain tissue extension. EXPN4 was the most abundant EXPN in the ovary tissues, while EXPN10 and EXPN7 act predominantly in ovary and pericarp tissues, and EXPN1 and EXPN15 in the embryo tissues. These results suggest that EXPN genes may control grain growth in sunflower from the early phases of development. Interestingly, EXPN7 and EXPN10 gene expression in the pericarp leveled off soon after flowering (+ 8 DFA), which is close to the maximum pericarp water content reached at + 10 DFA, indicating that EXPN and maternal tissue water dynamics may be linked in sunflower. These results contribute to improve the understanding of GW and grain size determination in sunflower and other grain crops.

\section{Methods}

\section{Experiments, treatments, and field conditions}

Two field experiments were carried out at the Experimental Station of the Universidad Austral de Chile in Valdivia $\left(39^{\circ} 47^{\prime} \mathrm{S}, \quad 73^{\circ} 14^{\prime} \mathrm{W}\right)$ during the $2013 / 14$ (experiment 1) and 2014/15 (experiment 2) growing seasons. Experiments were designed to evaluate relationships between EXPN expression patterns and sunflower reproductive organ dynamics (ovary weight, $\mathrm{GW}$, and grain water content and dimensions), both at pre- and post-flowering.

In experiment 1, plant reproductive organs and EXPN expression were measured in the sunflower oilseed hybrid Alybro, which corresponds to a hybrid with a short cycle and adapted to the environmental conditions of southern Chile. It was sown on November 2 in 2013 in a randomized complete design with three replicates. Experiment 2, aimed to validate the results of the first experiment by including an additional sunflower genotype contrasting in GW (confection variety RHA280, also with a short cycle and similar phenology to Alybro), and two source-sink treatments (control and reduced source-sink ratio prior to anthesis), with the aim of decrease GW, and add a new scenario to study determinants of GW. This experiment was sown on 1 November 2014 in a split plot design, where main plots were assigned to source-sink treatments and sub-plots to the genotypes, with three replicates. Source-sink treatments were established by shading the plots from stages R2 to R5, for 16-17 days (see Table A1 in [14]). Shading treatments comprised black nets that intercepted $80 \%$ of incident radiation. Nets were supported by wooden structures over the treated plots as in previous evaluations [29, 67] and reported by Castillo et al. (2017) [14].

In both experiments, seeds of Alybro genotype were provided by Panam Chile and seeds of the confection variety RHA280 by Dr. Laura Marek from USDA-ARS, NCRPIS. Plots were $5 \mathrm{~m}$ long with 10 rows, $0.70 \mathrm{~m}$ apart and a seeding rate of 6 plants $\mathrm{m}^{-2}$. Each plot was fertilized at sowing with $100 \mathrm{~kg} \mathrm{P}_{2} \mathrm{O}_{5} \mathrm{ha}^{-1}$ and $132 \mathrm{~kg} \mathrm{~K}_{2} \mathrm{O} \mathrm{ha}{ }^{-1}$. Nitrogen fertilization was applied using $150 \mathrm{~kg} \mathrm{Nha}^{-1}$ at sowing and $150 \mathrm{~kg} \mathrm{Nha}^{-1}$ when floral stems appeared. Weeds, insects, and diseases were controlled in both experiments and drip irrigation was applied to avoid water stress.

\section{Phenology and plant sampling}

Crop phenology was recorded twice a week during the crop cycle (in both experiments), according to the scale proposed by Schneiter and Miller (1981) [68]. Flowers or grains were sampled from R3 to maturity every three days. Two capitula per replicate and peripheral grains (florets in the 3-9 circles counted from the outside of the head) were harvested from each sample. Fresh and dry matter, and flower or grain dimensions (divided into pericarp and embryo), were measured. Water content of flower, pericarp, and embryo tissues was calculated as the difference between fresh and dry weight. Grain dimensions (length, width, and height) were recorded quickly after being sampled in a subset of four peripheral grains per capitulum, using an electronic caliper (digital caliper, China) as in Hasan et al. (2011) [4]. At harvest, five capitula were sampled per repetition to measure average GW (from 0.25 of capitulum) in both experiments.

Grain volume was measured by water displacement of 10 grains per experimental unit at maturity. This procedure mirrors that used in other studies for wheat [69], sorghum [20, 70], maize [71], and sunflower [8]. For molecular analysis, another set of harvested flowers and grains were immediately preserved in cryotubes and immersed in liquid nitrogen. Each sample consisted of 10 ovaries (pre-anthesis sampling) and five grains (post-anthesis sampling) per capitulum, and were stored at $80^{\circ} \mathrm{C}$ until processing for gene expression evaluation.

\section{Molecular analysis: In silico analysis and primer design} Identification of putative EXPN genes expressed in sunflower grain tissues.

The first objective was to identify in silico EXPN genes expressed in sunflower reproductive organs. Well-characterized EXPN from Zinnia elegans (a relative of 
sunflower) were used as a query sequence (e.g. ZeEXP3: GenBank: AF230333.1) to search public databases of sunflower genome and transcriptomic data (https:// www.heliagene.org) using the BLAST tool. Putative EXPN genes were identified based on gene annotation, bioinformatics, and RNA sequencing analyses. In the sunflower genome portal, protein-coding genes were annotated using a three-step process considering reciprocal best hits in the SwissProt and TAIR10 databases (12,360 sunflower proteins), protein-domain content in Interpro $(26,646$ sunflower proteins), and similarity with plant proteomes (Ensembl release 30) or coverage of the transcript with RNA-sequencing data [42].

From the BLASTp results, we chose eight putative EXPN according to the expression patterns tool in the sunflower transcriptome database (Additional file 3: Figure S3). We selected EXPN that were expressed in grains, whether expressed specifically in grains as EXPN15 (Additional file 3: Figure S3 A) or expressed in grains and other tissues such as leaves, roots, style, ligule, stem, stamen, corolla, and bract (e.g. EXPN4, Additional file 3: Figure S3 B). Then we selected EXPN sequences expressed mainly in grains, with high expression levels (reads per kilobase per million mapped reads). We also performed BLASTp in the Heliagene platform to find orthologous genes of each sunflower EXPN in Arabidopsis, Brachypodium, and soybean proteome from predicted proteins (Table S1). All sunflower EXPN explored in grain tissues identified highly with their orthologs (most $>70 \%$ ), indicating that the protein domain is highly conserved in plants. Additional file 4: Table S1 shows the physical locations of EXPN on the sunflower genome, with each EXPN gene located on a different chromosome. Open reading frame length ranged from $1473 \mathrm{bp}$ (EXPN15) to $3239 \mathrm{bp}$ (EXPN4), with an average of 2368 bp. The identified EXPN genes encoded proteins ranging from 254 (EXPN11) to 311 (EXPN1.2) amino acids in length, with an average of 269 amino acids (Additional file 4: Table S1).

The eight sunflower EXPN (and the EXPN7 ortholog) were subjected to multiple sequence alignments using the MegAlign program with the CLUSTAL W algorithm [72]. The alignment between EXPN of sunflower and other species confirms the presence of two conserved domains in sunflower EXPN (Additional file 5: Figure S4). Selected sequences were also aligned to reveal the number of unique sequences. Sequences were searched against the non-redundant GenBank DNA and protein database using BLASTn and BLASTx $[73,74]$ and against the Uni Prot database resources using BLASTx. Sequences were used in BLASTx searches to confirm that they correspond to EXPN transcripts. Nucleotide sequences were also translated into protein using the ExPASy bioinformatic tool (https:// web.expasy.org/translate/) to mark off the coding region for designing specific primers.

\section{Primer design}

Specific primers were designed using the "PRIMIQUE" tool to detect different sequences of the gene family [75]. Two primer pairs were chosen for the same sequence, then tested and standardized for qPCR. We conducted a bibliographic search for sunflower reference genes that could be used as an endogenous control to normalize the data for differences in input RNA and the efficiency of reverse transcription between the various samples. We evaluated primers reported by previous studies for sunflower grain elongation factor 1 (EF1), S19 protein, $\beta$-tubulin, actin, ubiquitin, and 18S [73-80].

\section{RNA extraction and RT-PCR}

Total RNA was isolated using the RNeasy Plant Mini kit (Qiagen), according to the manufacturer's instructions. The kit provides a choice of lysis buffers depending on the amount and type of secondary metabolites in the tissue, thus standardizing the RNA extraction protocol. RNA quality and concentration was measured using spectroscopy with NanoQuant (Infinite M200, TECAN).

The isolated RNA was pretreated with DNaseI. First-strand cDNA was synthesized from $250 \mathrm{ng}$ RNA using the ImProm- $\mathrm{II}^{\mathrm{Tm}}$ Reverse Transcription System. The oligo(dt)16-18 primer/template mix was thermally denatured at $70{ }^{\circ} \mathrm{C}$ for $5 \mathrm{~min}$ and chilled on ice. A reverse transcription reaction mix was assembled on ice and contained nuclease-free water, reaction buffer, reverse transcriptase, magnesium chloride, dNTPs, and ribonuclease inhibitor. We added $1 \mathrm{U} / \mu \mathrm{l}$ of Recombinant RNasin ${ }^{\circ}$ Ribonuclease Inhibitor before the template-primer combination was added to the reaction mix on ice. Following an initial annealing at $25^{\circ} \mathrm{C}$ for $5 \mathrm{~min}$, the reaction was incubated at $42{ }^{\circ} \mathrm{C}$ for up to $1 \mathrm{~h}$. The synthesized cDNA $(20 \mu \mathrm{l})$ was stored at $-20^{\circ} \mathrm{C}$. As a negative control, an RNA sample was replaced by water in this procedure.

\section{Quantifying EXPN mRNA levels using real time PCR (qPCR)}

The qPCR reaction was performed in a final volume of $25 \mu \mathrm{L}$, containing $12.5 \mu \mathrm{L}$ Brilliant II SYBR Green PCR Master Mix (Stratagene, Agilent technologies), $1 \mu \mathrm{L}$ $10 \mu \mathrm{M}$ forward and reverse primers and $8.5 \mu \mathrm{L}$ of sterile deionized water. After an initial DNA polymerase activation step at $95^{\circ} \mathrm{C}$ for $10 \mathrm{~min}$, samples were subjected to 35 amplification cycles $\left(95^{\circ} \mathrm{C}\right.$ for $15 \mathrm{~s}, 60^{\circ} \mathrm{C}$ for $15 \mathrm{~s}, 72^{\circ} \mathrm{C}$ for $15 \mathrm{~s}$ ). No-template and no-transcriptase controls were included to detect genomic DNA contamination.

A melting curve was generated by incubating the reaction at $95^{\circ} \mathrm{C}$ for $15 \mathrm{~s}, 25^{\circ} \mathrm{C}$ for $1 \mathrm{~s}$, and $70^{\circ} \mathrm{C}$ for $15 \mathrm{~s}$, and then slowly increasing the temperature to $95^{\circ} \mathrm{C}$. The mRNA abundance of EXPN genes between grain tissues and development stage was determined using the method proposed by Pfaffl (2001) [81], where $\beta$-tubulin 
was used as an internal control. Gene expression files were exported and uploaded into LinRegPCR software for quantification analysis [82]. The normalization factor was calculated as the geometrical mean of the RT-qPCR data obtained from LinRegPCR analysis. The underlying mathematical algorithm calculates qPCR efficiencies via linear regression in the exponential part of the fluorescence curve [82]. After confirming the amplified specific products, a standard curve of each primer pair was created with the amplification product. A dilution of 1:1000 was prepared before seven serial dilutions were prepared by a factor of 10 , starting from the 1:1000 dilution of the previously amplified product. This was used to score the efficiency of the primers.

EXPN sequences were further verified by sequencing and the resulting chromatograms were viewed, evaluated, and aligned. Gene sequences were subjected to a homology search in the Heliagene portal (https://www.heliagene.org/) and National Center for Biotechnology Information database (https://blast.ncbi.nlm.nih.gov/Blast.cgi). To classify sunflower EXPN proteins into subfamilies, we searched orthologs of EXPN7 in Arabidopsis, soybean, rice, wheat, Bachypodium, and maize, and incorporated two non-related EXPNs such as a $\beta$-EXPN EXPB1 from maize and EXLX1 from Bacillus subtilis (sequences based in crystallographic structure). They were aligned with predicted protein sequences without signal peptides (presumably 25 to 28 amino-terminal peptide), considering only the conserved domains of EXPN. Multiple alignments were analyzed using MegAlign (CLUSTALW) and a phylogenetic tree of EXPN proteins was constructed using Lasergene software. The sunflower genome portal details the Gene Ontology enrichment tests with Blast2GO Pro (one-sided Fisher's exact tests, false discovery rate of $<0.05$ ) [42]. This information is reported in this study for each putative EXPN gene, together with the gene model and genome localization.

\section{Principal component analysis, hierarchical clustering, and heatmaps}

A heatmap was created to facilitate the graphical interpretation of the relationships between 13 different grain samples (ovary, pericarp and embryo) in different developmental stages using the Clustvis online tool with default settings ([42]; https://biit.cs.ut.ee/clustvis/). Heatmap can be used to visualize the data matrix of EXPN expression; the values in the matrix are color-coded, and we clustered the rows (EXPN expression patterns) by calculating all pairwise distances. Hierarchical clustering was performed using Pearson's correlation distance [83]. The dimensional expression data was reduced to two dimensions using Principal Component Analysis (PCA). Transformed and normalized gene expression values with $\log 2$ were used for analyzing the hierarchical clustering and PCA.

\section{Statistical analysis}

Data of variables and parameters of the ovary and grain growth dynamics were assessed using ANOVA (significant effects at $P<0.05$ for each factor and interactions), according to the experimental design described above. Regression analyses were used to evaluate the degree of association between variables using Statgraphics Centurion XVI software.

\section{Correlation analysis}

Correlation analysis between phenotypic data and gene expression was performed by $\mathrm{R}$ software (version 3.3.3), using the "rsgcc" package with the Gini correlation metric [84]. The $p$-value was calculated with 10,000 permutations with $\mathrm{P}<0.05$ as the chosen cut-off.

\section{Additional files}

Additional file 1: Figure S1. Identity and divergence percentage between EXPN evaluated based on multiple sequence alignment. Sequence aligngments of available full length amino acid sequence with EXPN signal peptide removed. SignalP 3.0 Server software was used to predict the signal peptide cleavage sites. (PDF $39 \mathrm{~kb}$ )

Additional file 2: Figure S2. Grain dynamics and relative expression patterns of six EXPN during ovary and grain growth in two sunflower genotypes under two source-sink treatments. (PDF $266 \mathrm{~kb}$ )

Additional file 3: Figure S3. Expression of putative EXPN in various sunflower tissues, according to the transcriptome database (heliagene). A. Scheme of EXPN15 expression. B. Scheme of EXPN4 expression. (RPKM: reads per kilobase per million mapped reads) were chosen. (PDF $187 \mathrm{~kb}$ )

Additional file 4: Table S1. Characteristics of putative sunflower EXPN. Accession name, chromosome localization, nucleotide and peptide sequence length, Blast2GO, orthologs, and \% identity. Data is from the sunflower genome database (Heliagene portal). (PDF 106 kb)

Additional file 5: Figure S4. Multiple sequence alignment of predicted protein sequences corresponding to plant orthologs of EXPN7 and eight putative sunflower EXPN. Identical amino acids are shown with black backgrounds, and different amino acids are shown without backgrounds. The potential putative catalytic domain ( $\mathrm{N}$ terminal) is indicated by a horizontal blue bar and the putative cellulose binding domain (C-terminal) is indicated by a horizontal red bar; both were predicted using ScanProsite. Multiple alignment was done using MegAlign software. (PDF $285 \mathrm{~kb}$ )

\section{Abbreviations}

DFA: days from anthesis; EXPN: expansin; GW: grain weight

\section{Acknowledgements}

We are very grateful to Dr. Laura Marek (USDA-ARS, NCRPIS) for providing RHA280 grains, Dr. Anita Arenas for advice on expression data analysis, and Dr. (C) Viviana Cavieres for graphical assistance. We also thank Magda Lobnik, Eusebio Miranda, and the personnel of the Experimental Field Station and Laboratory of Physiology and Molecular Biology of Crops, Universidad Austral de Chile, for their technical assistance. JC laboratory is partially funded by Instituto Milenio iBio - Iniciativa Científica Milenio MINECON.

\section{Funding}

This study was funded by the Chilean Technical and Scientific Research Council (CONICYT) Project FONDECYT 1141048 competitive grant. F.M. Castillo held postgraduate scholarships from CONICYT. 


\section{Availability of data and materials}

The data sets supporting the results of this article are included in the manuscript and its additional files. For further data and information of the experiments, please, contact the corresponding author.

\section{Authors' contributions}

DC conceived the project, designed the experiments and revised drafted manuscript. AC contributed to the design molecular experiments and supervised the data analysis and revised the manuscript. JC supervised the data analysis, performed correlation analysis and revised the manuscript. FC performed the field and molecular experiments, in silico identification and selection of the EXPN genes expressed in grains of sunflower, analysis of protein structures in silico, phylogenetic analysis, and the EXPN genes expression experimental work and analyzed the physiological and expression data, wrote the text and created all of the Figures for this manuscript. The authors have read and approved the final version of the manuscript.

\section{Ethics approval and consent to participate}

Not applicable.

\section{Consent for publication}

Not applicable.

\section{Competing interests}

The authors declare that they have no competing interests.

\section{Publisher's Note}

Springer Nature remains neutral with regard to jurisdictional claims in published maps and institutional affiliations.

\section{Author details}

${ }^{1}$ Graduate School, Faculty of Agricultural Sciences, Universidad Austral de Chile, Valdivia, Chile. ${ }^{2}$ Plant Production and Plant Protection Institute, Faculty of Agricultural Sciences, Universidad Austral de Chile, Valdivia, Chile. ${ }^{3}$ Institute of Biochemistry and Microbiology, Faculty of Sciences, Universidad Austral de Chile, Valdivia, Chile. ${ }^{4}$ Millennium Institute for Integrative Biology (iBio), Santiago, Chile.

\section{Received: 20 March 2018 Accepted: 19 November 2018}

\section{Published online: 04 December 2018}

\section{References}

1. Khoury CK, Bjorkman AD, Dempewolf H, Ramirez-Villegas J, Guarino L, Jarvis A, Rieseberg $\mathrm{LH}$, et al. Increasing homogeneity in global food supplies and the implications for food security. Proc Natl Acad Sci U S A. 2014;111(11):4001-6.

2. FAOSTAT. Crops Production. Food and Agriculture Organization of the United Nations, Statistics Division, http://www.fao.org/faostat/en/\#home 2015. (Accessed 20 ${ }^{\text {th }}$ March 2017)

3. Lizana XC, Riegel R, Gomez LD, Herrera J, Isla A, McQueen-Mason SJ, Calderini DF. Expansins expression is associated with grain size dynamics in wheat (Triticum aestivum L.). J Exp Bot. 2010;61:1147-57.

4. Hasan AK, Herrera J, Lizana XC, Calderini DF. Carpel weight, grain length and stabilized grain water content are physiological drivers of grain weight determination of wheat. Field Crop Res. 2011;123:241-7.

5. González FG, Aldabe ML, Terrile II, Rondanini DP. Grain weight response to different Postflowering source:sink ratios in modern high-yielding Argentinean wheats differing in spike fruiting efficiency. Crop Sci. 2014;54(1):297.

6. Borrás L, Maddoni GA, Otegui ME. Leaf senescence in maize hybrids: plant population, row spacing and kernel set effects. Field Crop Res. 2003;82:13-26.

7. Sala RG, Westgate ME, Andrade FH. Source/sink ratio and the relationship between maximum water content, maximum volume, and final dry weight of maize kernels. Field Crop Res. 2007;101:19-25.

8. Rondanini DP, Mantese Al, Savin R, Hall AJ. Water content dynamics of achene, pericarp and embryo in sunflower: associations with achene potential size and dry-down. Eur J Agron. 2009;30:53-62.

9. Breseghello F, Sorrells ME. OTL analysis of kernel size and shape in two hexaploid wheat mapping populations. Field Crop Res. 2007;101:172-9.
10. Gegas VC, Nazari A, Griffiths S, Simmonds J, Fish L, Orford S, Snape JW. A genetic framework for grain size and shape variation in wheat. Plant Cell. 2010;22(4):1046-56.

11. Xing Y, Zhang Q. Genetic and molecular bases of rice yield. Annu Rev Plant Biol. 2010;61:421-42.

12. Li J, Nie X, Tan JLH, Berger F. Integration of epigenetic and genetic controls of seed size by cytokinin in Arabidopsis. Proc Natl Acad Sci U S A. 2013;110: 15479-84.

13. Zuo J, Li J. Molecular genetic dissection of quantitative trait loci regulating rice grain size. Annu Rev Genet. 2014;48:99-118.

14. Castillo FM, Vásquez SC, Calderini DF. Does the pre-flowering period determine the potential grain weight of sunflower? Field Crop Res. 2017; 212:23-33.

15. Connor DJ, Hall AJ. Sunflower physiology. In: Schneiter AA, Seiler GJ, Bartels JM, editors. Sunflower Technology and Production American Society of Agronomy; 1997. p. 113-82.

16. Calderini DF, Abeledo LG, Savin R, Slafer GA. Effect of temperature and carpel size during pre-anthesis on potential grain weight in wheat. J Agric Sci. 1999:132:453-9.

17. Calderini DF, Reynolds MP. Changes in grain weight as a consequence of de graining treatments at pre- and post-anthesis in synthetic hexaploid lines of wheat (Triticum durum x T-tauschii). Aust J Plant Physiol. 2000;27:183-91.

18. Ugarte C, Calderini DF, Slafer GA. Grain weigh and grain number responsiveness to pre-anthesis temperature in wheat, barley and triticale. Field Crop Res. 2007;100:240-8.

19. Adamski NM, Anastasiou E, Eriksson S, O'Neill CM, Lenhard M. Local maternal control of seed size by KLUH/CYP78A5-dependent growth signaling. Proc Natl Acad Sci. 2009;106:20115-20.

20. Yang Z, Oosterom EJV, Jordan DR, Hammer GL. Pre-anthesis ovary development determines genotypic differences in potential kernel weight in sorghum. J Exp Bot. 2009;60:1399-408.

21. Budzinski IG, Santos F, Sera TB, Pot T, Vieira LG, Pereira LFP. Expression patterns of three a-expansin isoforms in Coffea arabica during fruit development. Plant Biol. 2011;13(3):462-71.

22. Fang W, Wang Z, Cui R, Li J, Li Y. Maternal control of seed size by EOD3/ CYP78A6 in Arabidopsis thaliana. Plant J. 2012;70:929-39.

23. Xia T, Li N, Dumenil J, Li J, Kamenski A, Bevan MW, Gao F, Li Y. The ubiquitin receptor DA1 interacts with the E3 ubiquitin ligase DA2 to regulate seed and organ size in Arabidopsis. Plant Cell. 2013;25:3347-59.

24. Du L, Li N, Chen L, Xu Y, Li Y, Zhang Y, Li C. The ubiquitin receptor DA1 regulates seed and organ size by modulating the stability of the ubiquitinspecific protease UBP15/SOD2 in Arabidopsis. Plant Cell. 2014;26:665-77.

25. Brinton J, Simmonds J, Minter F, Leverington-Waite M, Snape J, Uauy C. Increased pericarp cell length underlies a major quantitative trait locus for grain weight in hexaploid wheat. New Phytol. 2017;215:1026-38.

26. Leon-Kloosterziel K, Keijzer C, Koornneef M. A seed shape mutant of Arabidopsis that is affected in integument development. Plant Cell. 1994:6:385-92.

27. Schruff MC, Spielman M, Tiwari S, Adams S, Fenby N, Scott RJ. The AUXIN RESPONSE FACTOR 2 gene of Arabidopsis links auxin signalling, cell division, and the size of seeds and other organs. Development. 2006;133:251-61.

28. Song X-J, Huang W, Shi M, Zhu M-Z, Lin H-X. A QTL for rice grain width and weight encodes a previously unknown RING-type E3 ubiquitin ligase. Nat Genet. 2007:39(5):623-30.

29. Lindström LI, Pellegrini CN, Aguirrezábal LAN, Hernández LF. Growth and development of sunflower fruits under shade during pre and early postanthesis period. Field Crop Res. 2006;96:151-9.

30. Lindström LI, Pellegrini CN, Hernández LF. Histological development of the sunflower fruit pericarp as affected by pre- and early post-anthesis canopy shading. Field Crops Res. 2007;103:229-38.

31. Wang E, Wang J, Zhu $X$, et al. Control of rice grain-filling and yield by a gene with a potential signature of domestication. Nat Genet. 2008;40:1370-4.

32. Ruan Y-L, Patrick JW, Bouzayen M, Osorio S, Fernie AR. Molecular regulation of seed and fruit set. Trends Plant Sci. 2012;17:656-65.

33. Sampedro J, Cosgrove DJ. The expansin superfamily. Genome Biol. 2005; 6(12):242

34. Cosgrove DJ. Plant expansins: diversity and interactions with plant cell walls Curr Opin Plant Biol. 2015;25:162-72.

35. Fleming AJ, McQueen-Mason S, Mandel T, Kuhlemeier C. Induction of leaf primordia by the cell wall protein expansin. Science. 1997;276:1415-8.

36. Link BM, Cosgrove DJ. Acid-growth response and a-expansins in suspension cultures of bright yellow 2 tobacco. Plant Physiol. 1998;118(3):907-16. 
37. Fry SC, Smith RC, Renwick KF, Martin DJ, Hodge SK, Matthews KJ. Xyloglucan endotransglycosylase, a new wall-loosening enzyme-activity from plants. Biochem J. 1992;282:821-8.

38. McQueen-Mason SJ, Durachko DM, Cosgrove DJ. Two endogenous proteins that induce cell wall extension in plants. Plant Cell. 1992;4:1425-33.

39. Marowa $P$, Ding A, Kong Y. Expansins: roles in plant growth and potential applications in crop improvement. Plant Cell Rep. 2016;35:949-65.

40. Bae JM, Kwak MS, Noh SA, Oh MJ, Kim YS, Shin JS. Overexpression of sweetpotato nsin cDNA (IbEXP1) increases seed yield in Arabidopsis. Transgenic Res. 2014;23(4):657-67.

41. Radchuk V, Weier D, Radchuk R, Weschke W, Weber H. Development of maternal seed tissue in barley is mediated by regulated cell expansion and cell disintegration and coordinated with endosperm growth. J Exp Bot. 2011;62:1217-27.

42. Badouin H, Gouzy J, Grassa CJ, Murat F, Staton SE. Cottret et al.. The sunflower genome provides insights into oil metabolism, flowering and Asterid evolution. Nature. 2017;546(7656):148-52.

43. Cosgrove DJ. New genes and new biological roles for expansins. Curr Opin Plant Biol. 2000;3:73-8

44. Choi D, Lee $Y$, Cho HT, Kende H. Regulation of expansin gene expression affects growth and development in transgenic rice plants. Plant Cell. 2003; 15:1386-98.

45. Cho $\mathrm{H}$, Kende $\mathrm{H}$. Tissue localization of expansins in Deepwater rice. Plant J. 1998;15:805-12.

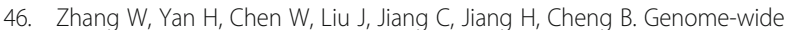
identification and characterization of maize expansin genes expressed in endosperm. Mol Gen Genomics. 2014;289(6):1061-74.

47. Garg R, Singh VK, Rajkumar MS, Kumar V, Jain M. Global transcriptome and coexpression network analyses reveal cultivar-specific molecular signatures associated with seed development and seed size/weight determination in chickpea. Plant J. 2017;91(6):1088-107.

48. Szymanski DB, Cosgrove DJ. Dynamic coordination of cytoskeletal and cell wall systems during plant cell morphogenesis. Curr Biol. 2009;19:R800-11.

49. Chen F, Dahal P, Bradford KJ. Two tomato expansin genes show divergent expression and localization in embryos during seed development and germination. Plant Physiol. 2001;127(3):928-36.

50. Harrison EP, McQueen-Mason SJ, Manning K. Expression of six expansin genes in relation to extension activity in developing strawberry fruit. J Exp Bot. 2001;52(360):1437-46.

51. Lindström LI, Hernández LF. Developmental morphology and anatomy of the reproductive structures in sunflower (Helianthus annuus): a unified temporal scale. Botany. 2015;10((November 2014)):1-10.

52. Kesavan M, Song JT, Seo HS. Seed size: a priority trait in cereal crops. Physiol Plant. 2013:147:113-20.

53. Becker MG, Hsu S-W, Harada JJ, Belmonte MF. Genomic dissection of the seed. Front Plant Sci. 2014:5:464.

54. Dante R, Larkins B, Sabelli P. Cell cycle control and seed development. Front Plant Sci. 2014:5:1-14.

55. Li N, Li Y. Maternal control of seed size in plants. J Exp Bot. 2015;4:1-11.

56. Orozco-Arroyo G, Paolo D, Ezquer I, Colombo L. Networks controlling seed size in Arabidopsis. Plant reproduction. 2015;28:17-32.

57. Fiqueiredo DD, Köhler C. Bridging the generation gap: communication between maternal sporophyte, female gametophyte and fertilization products. Curr Opin Plant Biol. 2016:29:16-20.

58. Jofuku KD, Omidyar PK, Gee Z, Okamuro JK. Control of seed mass and seed yield by the floral homeotic gene APETALA2. Proc Natl Acad Sci U S A. 2005;102:3117-22

59. Ohto M-A, Fischer RL, Goldberg RB, Nakamura K, Harada JJ. Control of seed mass by APETALA2. Proc Natl Acad Sci U S A. 2005;102:3123-8.

60. Li Y, Zheng L, Corke F, Smith C, Bevan MW. Control of final seed and organ size by the DA1 gene family in Arabidopsis thaliana. Genes Dev. 2008;22:1331-6

61. Zhang X, Hirsch CN, Sekhon RS, De Leon N, Kaeppler SM. Evidence for maternal control of seed size in maize from phenotypic and transcriptional analysis. J Exp Bot. 2016;6:1907-17.

62. Mu Q, Huang Z, Chakrabarti M, Illa- Berenguer E, Liu X, Wang Y, et al. Fruit weight is controlled by cell size regulator encoding a novel protein that is expressed in maturing tomato fruits. PLoS Genet. 2017;13(8):e1006930.

63. Simmonds J, Scott P, Brinton J, Mestre TC, Bush M, Del Blanco A, Dubcovsky J, Uauy C. A splice acceptor site mutation in TaGW2-A1 increases thousand grain weight in tetraploid and hexaploid wheat through wider and longe grains. Theor Appl Genet. 2016;129:1099-112.

64. Muñoz M, Calderini DF. Volume, water content, epidermal cell area and XTH5 expression in growing grains of wheat across ploidy levels. Field Crops Res. 2015;173:30-40

65. Xu B, Gou JY, Li FG, Shangguan XX, Zhao B, Yang CQ, Chen XY. A cotton BURP domain protein interacts with a-expansin and their co-expression promotes plant growth and fruit production. Mol Plant. 2013;6(3):945-58.

66. Chen Y, Han Y, Zhang M, Zhou S, Kong X, Wang W. Overexpression of the wheat expansin gene TaEXPA2 improved seed production and drought tolerance in transgenic tobacco plants. PLoS One. 2016:11(4):e0153494.

67. Cantagallo JE, Medan D, Hall AJ. Grain number in sunflower as affected by shading during floret growth, anthesis and grain setting. Field Crop Res. 2004:85:191-202.

68. Schneiter AA, Miller JF. Description of sunflower growth stages. Crop Sci. 1981;21:901-3.

69. Millet $\mathrm{E}$, Pinthus MJ. The association between grain volume and grain weight in wheat. J Cereal Sci. 1984;2:31-5.

70. Kiniry JR. Kernel weight increase in response to decreased kernel number in sorghum. Agron J. 1988;80:221-6.

71. Gambín BL, Borrás L, Otegui ME. Kernel water relations and duration of grain filling in maize temperate hybrids. Field Crop Res. 2007:101:1-9.

72. Thompson JD, Higgins DG, Gibson TJ. CLUSTAL W: improving the sensitivity of progressive multiple sequence alignment through sequence weighting, position-specific gap penalties and weight matrix choice. Nucleic Acids Res. 1994:22:4673-80.

73. Altschul SF, Gish W, Miller W, Myers EW, Lipman DJ. Basic local alignment search tool. J Mol Biol. 1990;215(3):403-10.

74. Altschul SF, Madden TL, Schaffer AA, Zhang J, Zhang Z, Miller W, Lipman DJ, Gapped BLAST. PSI-BLAST: a new generation of protein database search programs. Nucleic Acids Res. 1997;25:3389-402.

75. Fredslund J, Lange M. Primique: automatic design of specific PCR primers for each sequence in a family. BMC Bioinformatics. 2007:8:369.

76. Brunner AM, Yakovlev IA, Strauss SH. Validating internal controls for quantitative plant gene expression studies. BMC Plant Biol. 2004;4:14.

77. Oracz K, El-Maarouf-Bouteau H, Bogatek R, Corbineau F, Bailly C. Release of sunflower seed dormancy by cyanide: cross-talk with ethylene signalling pathway. J Exp Bot. 2008;59(8):2241-51.

78. Pramod S, Downs KE, Welch ME. Gene expression assays for actin, ubiquitin, and three microsatellite-encoding genes in Helianthus annuus (Asteraceae). Am J Bot. 2012;99(9):e350-2

79. Layat E, Leymarie J. El-Maarouf-Bouteau H, Caius J, Langlade N, Bailly C. Translatome profiling in dormant and nondormant sunflower (Helianthus annuus) seeds highlights post-transcriptional regulation of germination. New Phytol. 2014;204(4):864-72.

80. Meimoun P, Mordret E, Langlade NB, Balzergue S, Arribat S, Bailly C, ElMaarouf-Bouteau $\mathrm{H}$. Is gene transcription involved in seed dry afterripening? PLoS One 2014:9(1):e86442.

81. Pfaffl MW, Hageleit M. Validities of mRNA quantification using recombinant RNA and recombinant DNA external calibration curves in real-time RT-PCR. Biotechnol Lett. 2001;23:275-82.

82. Ruijter JM, Ramakers C, Hoogaars WMH, Karlen Y, Bakker O, Van den Hoff MJB, Moorman AFM. Amplification efficiency: linking baseline and bias in the analysis of quantitative PCR data. Nucleic Acids Res. 2009;37(6):e45.

83. Metsalu T, Vilo J. Clustvis: a web tool for visualizing clustering of multivariate data using principal component analysis and heatmap. Nucleic Acids Res. 2015:43(W1):W566-70

84. Ma C, Wang X. Application of the Gini correlation coefficient to infer regulatory relationships in transcriptome analysis. Plant Physiol. 2012;160(1):192-203. 